\title{
Learning from Labor? \\ Welfare policy transfer between Australia and Britain
}

\author{
Chris Pierson \\ Discussion Paper No.86
}

July 2001

ISBN 0731534298

ISSN 10302190 


\begin{abstract}
The evidence is examined for (and against) a process of policy transfer in the early 1990s between the Australian Labor Party (then in government) and policy reformers in the Labour Party in the UK in the two areas of 'welfare to work' (especially the JET initiative) and, rather more briefly, child support. Policy transfer of the JET was broadly successful while the transfer of the CSA initiative failed. Policy transfer is a real process but also complex and uncertain. The extent of transfer is conditioned by factors such as the extent of dissatisfaction with existing arrangements and the adequacy of local policy advice.
\end{abstract}

\title{
Author's Note
}

The research upon which this paper is based was generously supported by an award from the Economic and Social Research Council of the UK (Research Award R000222694) and a Research Professorship at the Australian National University in Canberra. This support is gratefully acknowledged. Interview material cited in the text is drawn from a series of interviews conducted in Canberra and London between July 1999 and October 2000. Australian spellings are frequently Americanised. I exploit this to distinguish between the ALP (Labor) and the UK Labour Party (Labour). Generic usages are rendered in BritishEnglish. In Australian discussions, 'pensioners' refers to those in receipt of any state benefit, not only those receiving age-related benefits.

School of Politics

University of Nottingham

UK 


\section{Introduction}

Policy transfer is a long-established process. The ancient Greeks have had many imitators as well as admirers and the impact of Roman imperial outreach can still be seen across Europe and beyond. Indeed, once we bring the coercive transfer of policies and programmes within our remit, we can see that much imperial history, not least the history of the British Empire, can be re-written as a series of such transpositions. If we focus more narrowly upon specific programmes, it is clear again that the process of transfer - whether by borrowing, imitation or imposition - is long established. In the great period of welfare programme innovation in the quarter century before the First World War, there was an almost constant traffic in political delegations and investigating commissions sent out to report on developments abroad with a view to informing reform at home. This was a process already happening upon a surprisingly global scale (Pierson, 1998, 99-108).

Despite these considerable precedents, the systematic investigation of policy transfer between notionally independent political jurisdictions is of comparatively recent origin. It may first have emerged amongst American political scientists, interested in the process (rather than the substance) of policy diffusion between the individual states of the Union (Walker, 1969). There are also important forerunners in the literatures on policy learning across public bureaucracies (Heclo, 1974) and on the diffusion of welfare policies (Collier and Messick, 1975). But it only very recently, and with due acknowledgement to the innovating work of Richard Rose and Colin Bennett in the 1980s, that policy transfer has emerged quite explicitly as a central focus for work in comparative politics in the UK (Rose, 1991; Rose, 1993; Rose, 2000; Bennett, 1988; Bennett, 1991; Dolowitz, 1997; Dolowitz, 1998; Dolowitz and Marsh, 1996; Dolowitz and Marsh, 2000; Evans and Davies, 1999; Page, 2000; Stone, 1999; Stone, 2000).

Much of this work is programmatic in character and it has given rise to a diverse terminology. 'Policy transfer' is increasingly distinguished from 'policy diffusion' and 'policy convergence' (both of which can be seen as more generic categories) and from 'lesson learning' (which implies a resolutely voluntaristic framework). Rose (1991, 1993, 2000), focussing on the possibilities for such 'lesson learning', describes a range of responses which run from explicit 'copying' through 'emulation', 'hybridization' and 'synthesis' towards the much less concrete category of policy 'inspiration'. Bennett (1991) prefers a fourfold classification of 'emulation', 'elite networking', 'harmonization' and finally 'penetration', the last indicating transfer by imposition. Dolowitz and Marsh $(1996,2000)$ develop a hybrid account which combines a modified version of Rose's analysis with an insistence upon the importance of non-voluntary transfer captured in the idea of 'coercive transfer' which may, in turn, be either 'direct' or 'indirect' (Dolowitz and Marsh, 1996, 2000).

Although there is no uniform agreement about how we can be sure that a transfer really has taken place, something of a consensus has emerged around Dolowitz and Marsh's definition of what policy transfer is:

A process by which knowledge about policies, administrative arrangements, institutions and ideas in one political system (past or present) is used in the development of policies, administrative arrangements, institutions and ideas in another political system. (Dolowitz and Marsh, 2000, p. 5)

We can find broad agreement around the following points as well. First, the existing literature is dominated by case studies which tell us too little about the general circumstances in which policy transfer is likely to arise, who is likely to initiate it and why, what form it is likely to take and the probabilities of its being successful (as well as lacking a specification of what would count as transfer 'success' or 'failure'). Secondly, we lack a really good metric (and methodology) for determining how much transfer of what kind has taken place. Too much of the evidence upon which we must rely is either anecdotal or circumstantial - or both. Finally, the process of transfer (rather than its 
typology) is under-theorised, though some may be quite happy to leave it that way (see Evans and Davies, 1999; Page, 2000).

The principal purpose of this paper is to establish the evidence for (and against) a process of policy transfer in the early 1990s between the Australian Labor Party (then in government) and policy reformers in the Labour Party in the UK in the two areas of 'welfare to work' (especially the JET initiative) and, rather more briefly, child support. In the closing section of the paper, I consider what these particular cases may tell us about the more general parameters within which the analysis of policy transfer may (or may not) work.

\section{Context}

The period under consideration here runs from the start of the 1990s until 1996 (the year in which the ALP lost its first Federal Parliamentary election since 1983). At the start of the period, Bob Hawke was in his seventh year as Australian Prime Minister. He was to be replaced by Paul Keating in a messy party coup in December 1991. In Britain, Labour had entered its second decade of opposition under the leadership of Neil Kinnock. The Policy Review process, the major policy reappraisal set in train after Labour's third consecutive and comprehensive defeat in the 1987 Election, was yet to be completed (in anticipation of the General Election that was to be held in 1992). The fortunes of the two parties stood in the starkest contrast. The ALP had just won its fourth consecutive federal election under Hawke. Labour had not won an election at the national level for more than fifteen years.

\section{Recognition}

Evans and Davies (1999, p. 377) argue that the potential for voluntary transfer exists whenever 'enough dissatisfaction or necessity exists and providing that an entrepreneurial elite is ready to manipulate these grievances and establish a transfer network'. The dissatisfaction at the highest levels of the Labour Party in the wake of its defeat in 1987 is by now fairly exhaustively established, although there was still very considerable disagreement about how far-reaching the process of programmatic revision should be (see Shaw, 1996). Programmatic renewal was also seen to be very much entwined with issues of party management and the reform of the decision-making procedures of the party itself. Although there was plenty of disagreement about the best way forward - and about 'how far the party should go' - there were few in the senior ranks of the party after 1987 who did not believe that Labour faced a problem. For this elite, 'the problem' was complex, including a declining electoral base, cumbersome internal decision-making processes, an old-fashioned image and a raft of policy pledges which simply made the party's other difficulties more acute.

\section{Search}

If the party at its most senior levels recognised that it had a problem - and a problem that was at least in part about its repertoire of policies - this did not immediately translate into the creation of a 'policy transfer network'. The party sought alternatives (above all something that would enable it to stop losing elections) but it is not clear that this was primarily about the transfer of policies from other polities. Certainly there was an appeal to experience overseas, principally to Europe (with Germany and Sweden well to the fore) and sometimes to Japan (still then in the throes of its economic miracle). But Labour's revision at this stage was much more resolutely domestic. It was oriented around how much (or how little) of Thatcher's reform it was willing to swallow (or to countermand). Despite the presence in Neil Kinnock's immediate circle of Patricia Hewitt (Australian born and raised) and the evident electoral success of the ALP throughout the 1980s, the influence of the Australian example was quite limited. Indeed, Hewitt argues that in the late 1980s, the ALP was seen as too far to the right (on issues such as privatization and tax cuts, for example) to be seen as a model for Labour in Britain (Hewitt interview). As Labour moved rightwards and as the ALP reinforced its record as a 
government capable of re-election, this situation gradually changed. In its turn, this process was somewhat eclipsed by the rise of Clinton, the 'New Democrats' and 'the third way', all of which had a more marked impact upon Labour's continuing revision in the early 1990s. (The process of policy transfer from the New Democrats to New Labour has been extensively reported; see, for example, Dolowitz, 1997; Dolowitz, 1998; King and Wickham-Jones, 1999; Deacon, 2000).

\section{Contact}

Of course, Britain and Australia are geographically rather distant but this physical separation is outweighed by ties of history, culture, kinship and language. In terms of historical policy transfer, it is clear that most of the traffic has travelled eastwards from Britain to Australia, which still (just) retains the British monarch as its head of state. Indeed, in their origins, the new colonies were a direct outgrowth of British state policy and the British Crown was a dominant force in the development of Australia all the way down to Federation - and some way beyond. (As late as 1975, the Queen's representative in Australia was able to sack the Labor government, albeit with the active complicity of the opposition parties; Kelly 1976). Interaction between the two labour parties persisted throughout the twentieth century. But for most of that time the expectation was that the flow of ideas and policies was largely one-way - from Britain towards Australia. Jim Jupp, whose experience of both parties in the second half of the twentieth century is unrivalled, was characteristically direct when he wrote in 1964 that 'the main difference between the British Labour Party and the ALP is that the British party is much better'. The ALP prided itself upon being even more anti-intellectual than the British Labour Party (no small claim!). It certainly had fewer university-educated leaders (Jupp, 1964 and interview). Its participation in the Socialist International was also quite limited, even into the epoch of Hawke and Keating (interview with Lord Murray Elder). Even critics of the ALP's record as a party of the left tended to borrow the language and devices of the New Left in Britain, whilst giving their account a distinctively Australian twist (see, for example, McQueen, 1970; Catley and Macfarlane, 1974). (For an excellent general treatment of relations between the ALP and British Labour, see Scott, 2000).

To some extent this relationship, and with it the direction of the flow of ideas and certainly experience, changed in the 1990s. It has been suggested that relationships between Kinnock and Hawke were somewhat frosty (interview with Gary Gray, National Secretary of the ALP, 1993-2000). But in 1990, the British leader sent the then rising stars of his Shadow team, Gordon Brown and Tony Blair, on a party visit to Australia (Scott, 2000). As a child, Blair had lived briefly in Adelaide and he had visited previously in 1982 (the year before he entered parliament). He had longstanding friendships with Geoff Gallop (subsequently Prime Minister of Western Australia) and Peter Thompson (the Anglican clergyman most closely associated with the mysteries of Blair's 'Christian socialism'). He also renewed acquaintance with Kim Beazley (later to be leader of the ALP, then a youthful but well established member of Hawke's cabinet) whom he had known at Oxford in the 1970s. Blair also struck up an immediate rapport with Keating, the Treasurer and soon to be Federal Prime Minister (see Scott, 2000). Coverage of this visit was understandably quite modest but when Blair returned (twice) in 1995, it was in a blaze of publicity. Much of the attention was directed to Blair's meeting with Rupert Murdoch, the head of News Corporation, but he was treated by much of the Australian press as the British Prime-Minister-in-waiting (Press archive of the ALP, Canberra). John Prescott, Blair's deputy, also visited in 1995 tasked with seeking to maximise the considerable British ex-pat vote in Australia in the forthcoming General Election.

In between, there were a series of official and unofficial party visitors. Notable amongst these was Murray Elder, chief of staff to John Smith in the brief period of the latter's leadership of the Labour party, who visited Canberra at the very end of 1993. Patricia Hewitt, at the time Deputy Director of the Institute for Public Policy Research and subsequently a minister in the Department of Trade and Industry, visited Australia regularly in the early 1990s. A number of her peers from High School days were now influential Federal 'femocrats' (Hewitt interview). Certainly contacts between the two parties were sufficient to allow for the transfer of policy ideas. 


\section{POLICY TRANSFER IN PROCESS}

Elites within the British Labour party recognised that they had a problem with, at its simplest, two inter-related dimensions: policy ineffectiveness and electoral unpopularity. It therefore had an incentive to seek out models which promised to deliver policies which would be both effective and popular. We have established that whilst Labour had longstanding links with the ALP, the extent of policy transfer from Australia to Britain historically had always been quite limited. We have also seen that there were both reasons and opportunities for this relationship to change by the start of the 1990s. In the sections that follow, I seek to trace in some detail the sometimes opaque trajectories of transfer through the 1990s.

\section{'Inspiration'}

At the most nebulous end of Richard Rose's classification of the media of policy transfer lies the category of 'inspiration', though in the end Rose insists that this is in fact 'not a form of lessondrawing but a form of speculation' (Rose, 1991, 29). This judgement may reflect Rose's own particular interest in the transfer of highly specific programmes. The category of inspiration should not be too readily dismissed. The inspirational example may be used not only to shape policy reformulation but also as a weapon in the reforming process - showing the doubters that change can work or, indeed, that only change can work.

This was certainly the way in which Blair talked about the Australian example on his visits in 1995. Blair was repeatedly asked what lessons he drew from the success of Australian Labor. Always at the top of his list was the ALP's capacity to win elections and retain office (see Blair 1995). But Blair also repeatedly insisted that the ALP proved that it was possible (and popular) to combine economic growth (and deregulation) with a commitment to communal well-being:

There are ... very powerful lessons in the way that the Australian Labor government has delivered greater economic efficiency, very high rates of growth at the same time as keeping true to strong social values and a good social wage.

Asked explicitly if the ALP was a 'model' for the British Labour Party, he replied:

... the ALP has got a lot that we can learn from. It combines a very tough headed practicality with strong social values. It has got a good relationship not just with public enterprise but with the private sector and it has had a very successful campaigning record as a political party and has become, in a sense, the natural party of government in Australia.

(Blair, 1995)

It is hard to think that Blair first developed his enthusiasm for the tough economy with a social conscience from looking at Australia but (when every allowance is made for the imperatives of being a polite visitor) it does appear that Blair saw value in the Australian experience because it showed 1) that this strategy could be delivered ,2) even when this was begun in the face of party hostility and 3) that it was electorally popular. Blair also looked to Keating's rhetoric and practice for a vindication of his judgement that processes of globalisation both made the 'old' social democracy unworkable and presented new opportunities to a reforming centre-left party willing to embrace change.

\section{Electoral strategy}

Above all else, what the leaders of British Labour admired about the ALP was its extraordinary capacity to go on winning elections - including the seemingly 'unwinnable' election of 1993. In part, this was attributed to vote-getting policies but at least as much it was seen to be down to skilful and 
highly-disciplined party organization. In particular, Gary Gray had been extraordinarily effective in concentrating resources upon key seats and delivering a better than anticipated national outcome by 'over-performing' in Labor's target seats. This involved what were (at the time) quite innovative techniques in which pre-campaign polling was used (particularly in bye-elections) to influence the presentation of candidates and policies. Where appropriate, election literature emphasised the local connections of a candidate with the affiliation to the ALP systematically downplayed. Materials in the ALP's National Archives in Canberra and interviews with Patricia Hewitt, Murray Elder and Gary Gray make it quite clear that the lessons the British were keenest to learn from the ALP were electoral. (A simple bibliometric measure is that the ALP archive in Canberra has several shelves devoted to election material shared with the British Labour Party but just a few box files devoted to policy!) Although Elder's 1993 visit was ostensibly to look at the ALP's declaration of aims and values (it has its own largely forgotten version of Clause IV - the 'Socialist Objective', adopted in 1921), his personal recollection is that his 'real' mission was to look at ALP electoral strategy. Hewitt reports that the Australian experience had an impact upon Phillip Gould, Labour's own electioneering guru.

\section{'Welfare to Work'}

'Welfare to work' - the commitment to maximise workforce participation (and minimise 'welfare dependency') through a series of active labour market measures - was a 'flagship' policy of the New Labour administration after 1997. Its principle vehicle was the multi-faceted 'New Deal'. This programme was designed to deliver on the first half of New Labour's new welfare mantra: 'work for those who can, security for those who cannot' (Blair in DfEE, 1998, p. iii). The policy identified a series of categorical groups which might need assistance to acquire work - starting with the young unemployed, moving on through the long-term unemployed to lone parents and those with a disability. To these were added distinctive branches of the New Deal to offer assistance to partners of the unemployed and to those over 50. Characteristically, the programmes involve an element of job subsidy with a private sector employer, work placement in the voluntary sector or with an environmental task force (and with appropriate training) or full-time education. The system is built around a network of personal advisers and more or less intensive case management. For the young and long-term unemployed, participation is mandatory (with the sanction of a potential withdrawal of benefits).

By the time Labour came to power in 1997, the world was more or less awash with active labour market programmes. Of course, the preceding Conservative administration had made its own moves in this general direction (most conspicuously with the transition from Unemployment Benefit to Job Seeker's Allowance in 1994/5). Although Labour was keen to emphasise that which was distinctive about the New Deal, there was an important element of continuity with what had gone before. It is clear that Labour was drawing upon American experience, especially as mediated through the Clinton presidency, in presenting its account of the New Deal (see, for example, King and Wickham-Jones, 1999; Deacon, 2000). But instructively, the most detailed and systematic treatment of policy transfer in this area retraces the impact of American models back through the Major Administration to the reforms of the second half of the 1980s under Margaret Thatcher. According to Dolowitz, 'the Thatcher Government had already developed a British welfare-to-work system, with a fully integrated workfare regime, by 1990' (Dolowitz, 1998, p. 1).

What was perhaps most distinctive about the Clinton reforms, and what made them so crucial for Labour, was the way in which a series of labour market changes could be re-presented as a positive component of a new left-of-centre politics. Where the compulsion associated with labour market programmes had once been seen as coercive it now re-emerged as 'enabling', furnishing the unemployed with a new range of opportunities. Undoubtedly this fed upon a belief that 'passive' regimes of employment assistance would never overcome the inertia that was thought to demobilise large numbers of the able-bodied unemployed - a view that had once been seen more or less as the monopoly of the political right, although it had long had a social democratic variant in the Nordic 
'work line' (see Mead, 1991; Murray, 1982; Eitrheim and Kuhnle, 2000). It also sought to capture for the 'progressive' wing of politics the belief that the political community was a locus of rights and responsibilities - opening up the spectre of a 'reciprocal obligation' or 'mutual obligation' between (workless) citizen and the state. This was once again a view which had been seen as very much the territory of the right. Crucial to this change was the sense that, if there were still plenty of economists who did not really believe this story about how labour markets worked, there were rather more middle class voters who did - and they were willing to reward parties who endorsed their judgement.

So Labour's policy built both upon prior experience at home (itself at least in part the product of an earlier round of policy transfer) and the always somewhat selective use of evidence from abroad. It is to American experience that both commentators and governments most frequently allude when seeking out the sources of policy transfer (Dolowitz, 1997; Dolowitz, 1998; King and Wickham-Jones, 1999; Deacon, 2000; government sources include DfEE, 1998). And with good cause. It seems clear that - politically, professionally and personally - these were the most important lines of communication over welfare reform. But they were certainly not the only source (as most such observers have been careful to record, if only in passing) and it is clear that Australian experience also fed into Labour's reform agenda.

\section{Learning from Australia}

The ALP had some of the same qualities as Clinton's New Democrats. It was a party that had won office (and secured re-election) on a ticket of economic reform and a break with its past. It had achieved a loosening of Australia's infinitely more rigid labour market and had done so without experiencing the catastrophic political meltdown of its neighbour across the Tasman Sea. Rather closer to the British Labour experience was the fact that the party leadership, Keating above all, had had to draw a rather reluctant party in its wake. Of course, the context was rather different.

Although Australia had a much more stringently regulated labour market, it had no history of social insurance for unemployment (or anything else). The ALP's commitment to active labour market reforms is widely associated with the process set in motion by Paul Keating following his (rather surprising) re-election in 1993 when he established a Committee on Employment Opportunities and an attendant Taskforce that went on to provide the basis for the White Paper Working Nation (Keating, 1994). Working Nation outlined a strategy that anticipated much of Labour's New Deal. At its core was the idea of a 'Job Compact' which was to apply to all those who had been in receipt of unemployment allowances for eighteen months or more. It provided for intensive individual case management, training and support to ensure that the unemployed person was made 'job ready', a job for 6 to 12 months ('primarily in the private sector'), a training wage 'combining employment with training leading to recognised and transferable skills' and 'intensive job search assistance'. There was to be a special Youth Training Initiative for those under eighteen, (Commonwealth of Australia, 1994, p 117). Most crucially, participation in the Job Compact was mandatory: 'Through the Compact, the Government will offer a job to those who have been on unemployment benefits for eighteen months or more. They in turn must take up the offer or they will lose their benefits' (Keating, 1994, p. 9).

Though it was presented as an innovation, in practice, Working Nation built upon more than a decade of labour market reform, stretching back at least to Bettina Cass's major Social Security Review in the mid-1980s which had pressed the case for an 'active employment strategy' (Cass, 1986). Australia has a long history of wage subsidies, public works and training programmes. Labour market programs had long been an element in regional policy and many programs had been directed to particularly disadvantaged communities (especially amongst Australia's aboriginal population). But from the 
mid-1970s, with the growth of unemployment, there was some tightening of the rules of eligibility for unemployment assistance. (One of the first provisions for tightening eligibility came under the Fraser Government in 1976 with the insistence that the work test could be failed 'on the grounds of unacceptable dress or appearance'!; Daniels, 1995, p.7) Following the Cass Report, the activity test for unemployment benefit was made more demanding, waiting periods were increased and the longterm unemployed were subject to reviews of their status. In 1987, the first 'Job Cubs' to assist in the process of job search were introduced. In 1988, Jobseekers Allowance replaced Unemployment Benefit for under eighteen-year-olds. In July 1991, Unemployment Benefit was abolished and replaced with Job Search Allowance (JSA) and Newstart Allowance (NSA). Recipients of the New Start Allowance (for those unemployed for more than twelve months) were required to enter into a Newstart Activity Agreement with the Commonwealth Employment Service - which might involve specific job search commitments, training, work experience etc. Failure to comply with an activity agreement could lead to a suspension of benefit (Daniels, 1995).

It is clear that there are very real parallels between the experience in Australia under the ALP and under 'New Labour' in Britain - and that, in some instances the Australian experience predated New Labour by almost a decade (for an excellent survey, see Finn, 1997). But this is not, of course, quite enough to prove a causal link between the two. Indeed, we might quite as plausibly argue that the impact of Australian reforms upon Labour in Britain was mediated through UK Conservative Governments in the UK which had also sought to learn lessons from the Australian experience. But many of the same ideas appeared still earlier in the United States in the Family Support Act (1988) which Dolowitz convincingly shows to be organically connected to still earlier initiatives at both federal and more especially state level. In that context, job search can be retraced to the Tax Equity and Fiscal Responsibility Act of 1982 and welfare-to-work programmes all the way back to the 1960s (Dolowitz, 1988, pp. 36-43).

Rather cheekily, and to some extent in the face of the evidence that the Working Nation reforms were informed by experience elsewhere, Keating claims that Australian labour market reforms shaped subsequent practice in both America and Britain (Keating, 1999). Although the claim owes something to Keating's immodesty, it is not entirely implausible. In the process of transfer, ideas change and, having changed, they may feed back into the system that spawned them. There is, for example, some reason to think that the version of welfare-to-work that reached Britain via Australia was a little less coercive and rather more generously funded than that which transferred directly across the north Atlantic. Certainly, this was precisely the sort of terrain on which New Labour sought to distinguish its welfare-to-work reforms from what it depicted as a more penal and mean-spirited predecessor. It was the way in which the ALP sought to distinguish its own record in government from the labour market programmes of the Coalition government that succeeded it in 1996 (ALP, 2000). Nor were Australia and the U.S. the only source for developments in the U.K. Scandinavian active labour market policies were of very long standing and many of the same ideas found their way into the thinking of elite policy makers through the agency of the OECD and the World Bank (see, for example, OECD, 1987; OECD, 1988; OECD, 1994; Kalisch, 2000). Indeed, it is clear that these international agencies are increasingly a clearing house for an international epistemic community of (social) policy makers who draw on OECD information as a ready source for the reform agenda at home (Haas, 1992; interview with Meredith Edwards, senior public servant in the early 1990s and a key figure in the development of Working Nation).

\section{JET (Jobs, Education and Training)}

If the precise lines of influence (and feedback) in the more general policy transfer process of welfareto-work are difficult to disentangle, there is at least one area in which we can trace quite clearly the impact of a specifically Australian initiative: that is, the Jobs, Education and Training (JET) program. The JET program was established in March 1989. Its aim was 'to provide the advice and practical help sole parent pensioners need to enter or return to employment: the ultimate objective being to 
increase their income and reduce pension expenditure' (DSS, 1992). It was a voluntary and multiagency program targeted at unemployed sole parents with older children, those who were long-term unemployed or teenagers. It involved targeted counselling, assistance with childcare, training and education. Costs would be heavily front-loaded but there was an expectation that eventually JET should increase pensioners' income whilst reducing public expenditure on their support. Early evaluations suggested that the program had made a real if limited difference (DSS, 1992). By 1996, more than 250,000 'customers' had been referred to the JET program. In 1998, the program was reported to be delivering annual net savings of about $\$ 121$ million (FACS, 1998).

Following defeat at the 1992 election, Labour elected a new leader. One of John Smith's first initiatives was to establish a Commission on Social Justice under the auspices of the independent (but sympathetic) auspices of the Institute for Public Policy Research (IPPR) and the chairmanship of Sir Gordon (later Lord) Borrie. The task of the Commission was to consider how the left's traditional aspiration to social justice might be delivered within the framework of a modern social and economic order. Amongst the key players on the Commission were Patricia Hewitt and David Miliband (secretary to the Commission and later to head the Prime Minster's Policy Unit under Tony Blair). By some way the longest and most detailed section of the Commission's final report published in 1994 was that devoted to the reform of the welfare state. The authors of the report were especially concerned with reforming the social security regime to take account of the new economy and new patterns of family formation (and dissolution). The Commission was fulsome in its reporting of the several virtues of JET:

Australia has pioneered a JET programme for lone parents which has, over the last five years, reached nearly half of that group, significantly raising levels of training, employment and earnings amongst its clients. Savings have consistently outstripped targets and are now close to the overall programme costs. Indeed the programme has been so successful that the Australian government is now considering extending it to the registered long-term unemployed. (Social Justice Commission, 1994, p. 172)

The recollections of Hewitt and others involved in the Commission's work indicate that JET was an important example - with lessons that might be applied well beyond its original target population amongst unemployed sole parents (Hewitt 2000; interview with David Miliband, head of Prime Minister's Policy Unit).

Although the influence of the Commission's report upon Labour in power was more limited than some had expected (by the time Labour came to power it had had a further three years in which to move away from even the Commission's qualified endorsement of universalism), it was real. JET reappears in the 'Road to the Manifesto', the series of documents that foreshadowed the commitments Labour would make in the 1997 General Election. By this stage, welfare-to-work was at the forefront of Labour's welfare policy. The strategy paper Getting Welfare to Work anticipates a transformed benefit system 'developing on a wider scale the lessons learned from the JET scheme in Australia, and personalising the services available to clients'. JET headed the Party's list of 'world's best practice' (Labour Party, 1996, p. 7; see also Harman, 1996, p. 8).

This commitment duly found its way into Labour's 1997 Election Manifesto:

Today the main connection between unemployed lone parents and the state is their benefits. Most lone parents want to work, but are given no help to find it. New Labour has a positive policy. Once the youngest child is in the second term of full-time school, lone parents will be offered advice by a proactive Employment Service to develop a package of job search, training and after-school care to help them off benefit. (Labour Party, 1997) 
The final stage in the process is implementation. The New Deal welfare-to-work programme, funded by a windfall tax upon the privatised utilities, was one of the first initiatives of the new Labour administration. The New Deal for Lone Parent (NDLP) was a key element in the programme. According to the DSS, this programme offers

a comprehensive package of back-to-work help, designed to help and encourage lone parents on Income Support to take up paid work; and improve the job-readiness of lone parents on Income Support and increase their employment opportunities. Personal advisers offer help and advice with job search, training, childcare and in-work benefits. Up-to-date information on job vacancies is also available. (DSSUK, 1999a).

Although participation was 'encouraged', initially the New Deal for Lone Parents was entirely voluntary. From April 2001, interviews with a Personal Adviser became compulsory for new or repeat lone parent claimants of Income Support. Recent modifications also include measures to improve in-work benefits and childcare support for programme participants, especially those working part-time. The DSS insists that the NDLP has already helped 80,000 lone parents to find work, whilst the number of lone parents claiming benefit has fallen by 130,000 since 1997 (DSSUK, 2001).

\section{The Child Support Agency: A Failed Hybrid?}

Despite the government's upbeat conclusions, the New Deal for Lone Parents, along with the other elements of JET that have found there way into the general welfare-to-work agenda, has not been unambiguously successful. Lone parents (generally lone mothers) and their children are still disproportionately poor, the take-up of employment and training opportunities is still patchy (for an interim evaluation, see Millar, 2000). There is still considerable resistance to the idea that best place for the mothers of young children is in the workplace (for a powerful statement of the case against greater participation, see Phillips, 1997). But, at least in terms of the policy-makers' manifest aims and objectives, the lessons of JET may be said to have been applied with some success and to have met with some degree of public acceptance. It would be difficult to make the same argument in terms of the unhappy history of the Child Support Agency (CSA). Although some of the heat has now gone out of this controversy, and the agency was further reformed under the Child Support, Pension and Social Security Act (2000), the introduction of the UK Child Support Agency in 1993 has often been counted as the second great policy disaster of the long period of Conservative government between 1979 and 1997 (outranked only, if at all, by the Poll Tax).

Unlike the poll tax, the Child Support Agency sought to implement a principle - that absent parents should shoulder a continuing financial responsibility for their children - which met with very widespread approval (Millar, 1996, p. 186). It was also a reform which had been introduced only a few years earlier in Australia, if not to universal acclaim then at least with widespread compliance, even amongst those who felt their interests were not well served by the new arrangements. The UK government was not only aware of the Australian experience. Senior civil servants had visited Canberra (and Wisconsin, of course) in preparing the White Paper Children Come First upon which the CSA legislation was based and had spoken of the Australian system having had 'a substantial measure of success' (DSSUK, 1990). Why did the Australian reform turn into a qualified success, whilst the British experience became a text-book case of policy failure?

Governments in both countries found themselves facing a broadly similar long-term social trend. In both countries, the number of lone parents had nearly doubled between the early 1970s and the late 1980s, whilst the proportion of those lone parents in employment had fallen. In Britain, by the end of the 1980s, the number of lone parents in receipt of income support had trebled and the cost to the public exchequer had doubled in less than a decade. In Australia, the number of lone parent 
pensioners increased by around about $60 \%$ through the $1980 \mathrm{~s}$, whilst the cost to the social security budget more than trebled between the early 1970s and the late 1980s (cited in Millar and Whiteford, 1993). Both governments sought reforms that would reduce the costs of lone parenthood to the public purse. And both sought out mechanisms that would take such settlements away from the adversarial process of the law courts. There were two routes to follow. The first was to use a mixture of incentives and sanctions to increase the labour force participation of lone parents (broadly the strategy of JET, the New Deal for Lone Parents and its antecedents). The second approach was to increase levels of child maintenance provided by 'absent' parents (generally estranged fathers). This was the policy purpose to be served by the Child Support Agency.

Beyond these shared objectives lay a number of important differences between Australian and British experience and it is amongst these that we should probably search for an explanation of the 'failure' of the policy to transpose successfully to the British context. First, the process of policy-making and evaluation was all together more measured in the Australian case. Formal interest in a reform of child maintenance in Australia can be retraced to the deliberations of a Parliamentary Joint Select Committee in 1979. This was followed by a further inquiry in 1983 and a Cabinet Sub-Committee Discussion paper published in 1986. An intensive public debate ensued (Maclean and Warman, 2000, p. 173). The Australian Child Support Scheme was finally introduced in 1988 to 'strike a fairer balance between public and private forms of support [for children] to alleviate the poverty of sole parent families' (Cabinet Sub-Committee on Maintenance, 1986; emphasis added). The reforms were introduced in two stages. Stage One involved the establishment of a Child Support Agency and changed arrangements for the collection of existing maintenance orders (through the Australian Tax Office). The second stage dealt with the transfer from the legal settlement of maintenance to a formula-driven administrative setting of child support obligations. The new measures only applied to the support of the children of couples who separated after the start-up date in 1989. After this cautious and gradual inception, the agency and its work was subjected to regular and systematic review and evaluation (see Maclean and Warman, 2000, p.176).

By contrast, in the UK, there was limited formal interest in the issue of child maintenance until an inter-departmental committee was established to review existing arrangements in 1989. A White Paper was published late in 1990 and, following a cursory six-week consultation period, legislation was introduced early in 1991. These were the 'high Jacobin' days of Conservative government in which new legislation was introduced with a minimum of notice and/or parliamentary scrutiny. The Child Support Agency opened for business in 1993. Almost at once, its administrative incompetence became the stuff of legend. Up to half its assessments were said to be inaccurate and it failed to meet just about every performance target it was set. The first Chief Executive resigned after sixteen months and the agency was repeatedly and severely criticised in Parliament, by the Ombudsman and by the National Audit Office. The Social Security Select Committee described the agency's performance over its first eighteen months as 'dire' (Craig et al, 1996).

Governments in Australia and the UK were both seeking a reduction in the public costs of lone parenthood. But it seems clear that whilst for the UK government this concern was paramount, Australian governments had a rather broader concern. In Australia, the rise of the CSA coincided with a wave of concern about levels of child poverty, prompting Bob Hawke's infamous 'commitment' at the 1987 election that 'by 1990 no Australian child will be living in poverty' (cited in Kelly, 1994, p. 350). Although Hawke's declaration met with intense scepticism, the Labor government did introduce a new family allowance supplement which benefited up to half a million families with children. The Australian government did expect that a new child maintenance regime would improve the incomes of poorer lone parents and this was explicitly an intention of the reform. To this end, it ensured that a significant proportion of any monies generated by the new settlement system would be retained by the 'care parent' (up to $75 \%$ of these monies in the case of maintenance awarded where the father had low earnings). By contrast, the UK government seemed wholly uninterested in the income status of lone parents. Maintenance would simply replace state benefits pound for pound - until the maintenance paid would take a family off benefits (DSSUK, 1990; 
Whiteford and Millar, 1993, pp. 64-7). Neither government was hugely successful in reducing the public costs of lone parenthood but the Australian government could claim to have delivered at least an incremental improvement in the incomes of poorer lone parents. The unrealistic targets for saving set by the UK Treasury probably contributed to the administrative failings of the CSA (see Eekelaar, 2000).

Compliance is a key element in any policy for delivering child maintenance. In the US, a number of individual states have tried (with relatively little success) to use the law to force defaulting absentee parents to pay up but it is extremely difficult to make the maintenance system work without a minimum of (however reluctant) compliance (Garrison, 2000, pp. 16/7). Of course, it is those 'absent' parents whose commitments are increased who are generally most dissatisfied with the new regime (though in the UK, the CSA managed to alienate a significant part of the lone parent population as well). In Australia, however, this opposition was effectively contained. In part, this was because there was no attempt to introduce a retrospective element into maintenance awards (for those who had reached a settlement prior to the introduction of the CSA deal in 1989). Generally adjudications were seen to correspond more closely to family circumstances and the means of both the 'absent' and the 'care' parent. More of the settlement went in additional resources to the child. Many absent parents resented making payments which simply reduced the state's costs and did nothing to improve the income status of their former family. Others resented the implicit element of maintenance to the 'caring parent' which was a part of the UK rubric. The competence of the collecting authorities plus the high levels of community acceptance of the principle of child maintenance also minimised noncompliance - though, of course, this remains a real and present problem.

In the UK, this grudging acceptance of the child maintenance regime was largely lacking. Noncompliance was encouraged by the administrative incompetence of the CSA and by the (probably well grounded) suspicion that in its revenue-maximising ambitions the CSA went after 'good' absentees, raising the charges upon those parents who were already paying maintenance, rather than seeking out the 'feckless' non-payers. In 2000, less than half of non-resident parents were fully compliant with their maintenance assessments. Nearly one third failed to pay at all (DSSUK, 2000). The complex mechanism for determining the level of liability plus the fact that all of the payment generally went to the state rather than the to the projected beneficiaries further undermined the legitimacy of the system. A series of high-profile suicides, attributed to the stresses of meeting unreasonable CSA demands and fuelled by an indignant middle-brow press - increased the sense of (self-) righteous indignation amongst a highly articulate group of deeply dissatisfied middle class absentee fathers.

The track record of the Australian CSA is far from perfect but the Annual Report for 2000 suggested that annual net savings from the programme had reached more than $\$ 200$ million by 1999 and that the agency was securing a collection rate of about $86 \%$ (FACS, 2000). It has been immeasurably more successful than its British counterpart which was subject to wholesale reform following the 1999 White Paper on Child Support (DSSUK, 1999b).

\section{Policy transfer: Learning the lessons}

A growing weight of empirical research (to which I have tried to make a modest addition here) demonstrates that policy transfer is a real process and, as politicians become ever more insistent upon 'evidence-based' policy advice, the rich resource that lies in the experience of policy-makers elsewhere is likely to be ever more frequently tapped. We can deploy a range of techniques (elite interviews, textual analysis of legal documents and government reports, the logging of international exchanges, mapping the sequential emergence of the 'same' policy initiatives and institutions in different times and places) to carry our accounts of this process beyond the anecdotal and to demonstrate that programmes and policies have been transferred. But at once we need to concede that this is a complex and rather uncertain process. Most transfer initiatives, even those which are most 
explicitly 'copied' from elsewhere, are an amalgam of importation and (often prior) indigenous practice. The 'same' policy may look quite different when managed by different public services or where the background conditions are very different. 'Failure' may occur at almost any stage in the process from first contact to final implementation. There are also methodological difficulties in establishing the extent of transfer, given that most borrowings lie somewhere along the continuum that runs from pure innovation to carbon copy. We can though make some tentative responses to the general questions raised in the introduction on the basis of the cases considered here.

First, the search for alternatives is likely to be initiated where there is a more or less intense dissatisfaction with existing arrangements. It is a commonplace of the policy literature that mild dissatisfaction, even when quite prolonged, is likely to produce tinkering rather than the quest for wholesale reform. In our example, it was the experience of more than a decade in opposition and the loss of four consecutive elections that triggered Labour's quest for a radically different take on welfare and the economy. Without John Smith's untimely death, change might have been still slower in coming - or there might just have been less of it. The transfer of policy is more likely, too, where a policy-making process has fallen into long-term disrepair or where it no longer commands effective support. Party revision usually starts as navel-contemplation. Only when this repeatedly fails to generate results should we expect a willingness to look elsewhere. The willingness to look overseas is also likely to be conditioned by the availability of alternative advice closer to home. During the Thatcher ascendancy, there was a ready supply of ideas in a range of right-wing think tanks whose policy entrepreneurs were ever eager to drive on the process of reform (see Denham, 1996). Left-ofcentre think tanks with a policy orientation were understandably much thinner on the ground through the 1980s and into the 1990s (a poverty which the inauguration of the Institute for Public Policy Research was designed to address). The international quest for policy alternatives is also likely to follow established patterns (again only themselves likely to be breached where these fail radically). Similarities of culture, public service, legal practice and above all language have long been seen to tie Anglophone polities into a distinctive 'family of nations' (Castles, 1993). The search for alternatives is likely to begin with those states which are seen to be most similar. Policy transfer is most likely where we encounter not just an intense dissatisfaction with existing provision but also an acute loss of faith in the traditional sources of policy solutions.

The research co-ordinated here suggests that it is not just governments and full-time officials who seek to transfer policies. Nor do politicians seek solutions only in the practice of ideologically similar parties. Parties in opposition regard themselves as governments-in-prospect and only ever a general election (and a little good fortune) away from holding the reins of state power. Of course, they lack many of the resources of incumbent governments and one good reason for partisanship in their policy quest is access. In the Australian case, contacts were as much party-to-party as opposition party-togovernment - in part, because what Labour really wanted to learn was how to win elections and this particular expertise was housed in the full-time party apparatus (around Gary Gray). More generally, it seems the impact of partisanship (particularly in government-to-government exchanges) may have been overplayed. Often the flow of information is between full-time officials rather than partisans. We have seen that UK Conservative governments were willing to learn from Australia even though it had a Labor government, whilst the ALP were happy to learn American lessons even though the White House was in the hands of the 'voodoo economists'. The flow of delegations from the UK to Wisconsin seems to be largely unaffected by changes of government! Nor is the partisan 'ownership' of particular policies always clear. There have always been left and right variants of 'welfare-towork' and, as we have seen, many of the American ideas that influenced 'New Labour' can be retraced through Conservative reforms. It is important not to confuse this with the rather different claim that 'parties do not matter'.

Although social policy has (until recently) been seen as one of then most resolutely domestic aspects of government policy, it has always been the site of a surprisingly international epistemic community (Haas, 1992; Pierson, 1998). Policy-borrowing in the welfare area goes back well over a century. It is clear that the transmission of information about policy is facilitated by the existence of an international social policy community, especially amongst those based in Anglo-American or 
Anglophone countries. The senior public servants and policy advisers in this virtual community share a common vocabulary. They move through the same international agencies, conferences and airport lounges. New forms of instantaneous global communication make the sharing of information easier and quicker, but sometimes less easy to follow and authenticate. A good example of these shared understandings is the impact of Richard Layard's 1986 manifesto, How to Beat Unemployment (Layard, 1986). In interviews, Layard's work was cited independently as a source of subsequent active labour market measures by Michael Keating and Meredith Edwards (both very senior public servants in Canberra in the early 1990s) and in the UK by Patricia Hewitt and Frank Field.

Learning is a partial and iterative process. This makes it extremely difficult to draw unambiguously the lines of policy transfer or even, sometimes, to establish the direction of transfer. Policy 'translation' is always mediated by contextual differences and a series of complex feedback mechanisms. Particular terminologies move through the international system but are often used to describe subtly different practices. The 'new' social policy is replete with such terms - job search, jobseekers' allowances, job clubs, new start, restart and so on. There is plenty of evidence of feedback in the Australia-UK-Australia nexus. Ideas which had part of their origins in the HawkeKeating ALP made their way into the 'New' Labour project. They now re-appear, suitably moderated, in the enthusiasm in key areas of the ALP for Labour's 'third way' (interview with Dennis Glover, policy adviser to Kim Beazley; Latham, 1998).

In the interests of economy and clarity, we might say that the policy transfer of JET was broadly successful (in the limited, though important sense of doing what its importers expected of it) whilst the transfer of the CSA initiative was (at least initially) a fairly spectacular failure. It is not possible here to give an exhaustive account of the differences but we can at least get some sense of why transfers fail. JET was a specific program with limited and clear objectives. Both in the UK and Australia, there was a recognition that in its early stages it would be expensive (though with the longer-term ambition that it would 'pay for itself'). It was in line with other elements of government reform, it was voluntary and it was unlikely to excite effective political resistance. The UK's Child Support Agency was seen quite explicitly as a device to save public money and to sanction 'irresponsible' parents. It was likely to antagonise its 'beneficiaries' (since lone mothers stood to gain little financially and were obliged to seek redress from their former partners) and was likely to antagonise a mobilisable and articulate group (of estranged fathers). The legislation was rushed through with very little discussion and cursory parliamentary scrutiny. Training and preparation for the establishment of the new agency was inadequate. The agency was burdened with unrealistic Treasury expectations. It involved compulsion and, worst of all, it made demands which it was then unable to enforce. It involved retrospective action and administrative practices (pursuing easy targets rather than the worst offenders) which were bound to bring it into disrepute. Of course, much of what was wrong with Britain's CSA has nothing to do with the process of policy transfer but these failings seem the more culpable in the light of the prior and much more successful Australian example.

One final curiosity. The whole process of reform under Hawke and Keating was carried through in a series of Accords between the ALP and the Australian trades union movement (brokered by its supersharp economist general secretary, Bill Kelty). In effect, wage restraint and deregulation of labour markets was traded off for a social wage and economic growth. Although some felt that the Accord was a rotten deal for the unions, it certainly delivered for its political supporters (Keating, above all). The original inspiration for the Accord process had lain in the (generally disastrous) attempts of Labour in Britain in the later 1970s to negotiate its own 'Social Contract' with the trade union movement (Keating interview). Rather exceptionally, this looks like an example of the export of a spectacular policy 'failure' which worked in its new location! The lesson is that whilst policy transfer is a real and probably a growing process, we need constantly to check our general expectations against the available historical record. 


\section{References:}

ALP: Australian Labour Party (2000) Party Platform 2000 (Canberra: ALP). Bennett, C.J. (1988) 'Different processes, one result: the convergence of data protection policy in Europe and the United States, Governance, 1, 425-41.

Bennett, C.J. (1991) 'Review Article: What is Policy Convergence and What Causes It?', British Journal of Political Science, 21, 215-33.

Blair, Tony (1995) 'Press Conference', Cairns, Queensland, $16^{\text {th }}$ July.

Cabinet Sub-Committee on Maintenance (1986) Child Support: a discussion paper on child

maintenance. Canberra; Australian Government Publishing Service.

Cass, B. (1986) The case for review of aspects of the Australian social security system Canberra:

Australian Government Publishing Service.

Castles, F.G. ed., (1993) Families of Nations. Aldershot: Dartmouth.

Catley, R. and McFarlane, B. (1974) From Tweedledum to Tweedledee.

Artarmon, NSW.: Australia and New Zealand Book Company.

Collier, D. and Messick, R.E. (1975) 'Prerequisites versus diffusion: testing alternative explanations

of social security adoption', American Political Science Review, 69, 4, 1299-315.

Commonwealth of Australia (1994) Working Nation: Policies and Programs Canberra:

Commonwealth of Australia.

Craig, G., Glendinning, C. and Clarke, K. (1996) 'Policy on the Hoof: The British Child Support Act in Practice', Social Policy Review, 8, 106-24.

Daniels, D. (1995) 'Social Security Payments (2)', Australian Parliamentary Background Papers.

(www.aph.gov.au)

Deacon, A. (2000) 'Learning from the US? The influence of American ideas

upon 'new labour' thinking of welfare reform' Policy and Politics, 28, 1, 5-18.

Denham, A. (1996) Think Tanks of the New Right. Aldershot: Dartmouth.

DfEE: Department for Education and Employment, (1998) A New Contract for Welfare: Principles into Practice London: H.M.S.O. Cmnd. 4102

DSS:Department of Social Security, Australia (1992) Jobs, Education and Training (JET):

Evaluation Report, Canberra: Social Policy Division, DSS Australia.

DSSUK: Department of Social Security, UK (1990) Children Come First, London:HMSO. Cmnd 1263.

DSSUK: Department of Social Security, UK (1999a) Opportunity for All: Tackling Poverty and Social Exclusion (www.dss.gov.uk/publications/dss/1999/poverty/main/chapt3d.htm)

DSSUK: Department of Social Security, UK (1999b) The 1999 Child Support White Paper, London: H.M.S.O. Cmnd. 4536

DSSUK: Department of Social Security, UK (2000) Child Support Agency - Quarterly Summary of Statistics, London: DSS Analytical Services Division

DSSUK: Department of Social Security, UK (2001) 'New Deal for Lone Parents'

(www.newdeal.gov.uk/english/lone parents).

Dolowitz, D.P. (1997) 'British Employment Policy in the 1980s: learning from the American Experience', Governance, 10, 1, 23-42.

Dolowitz, D.P. (1998) Learning from America: Policy Transfer and the Development of the British

Workfare State. Sussex: Sussex Academic Press.

Dolowitz, D.P. and Marsh, D. (1996) 'Who Learns What form Whom: a Review of the Policy

Transfer Literature', Political Studies, 44, 343-57.

Dolowitz, D.P. and Marsh, D. (2000) 'Learning from Abroad: The Role of Policy Transfer in Contemporary Policy-Making', Governance, 13, 1, 5-24.

Eekelaar, $\quad * * * * * * * * * * * * * * * \quad$ in J.T. Oldham and M.S. Melli, (eds), Child Support the Next Frontier, Ann Arbor: University of Michigan Press, pp.

Eitrheim, P. and Kuhnle, S. (2000) 'Nordic welfare states in the 1990s: institutional stability, signs of divergence' in S. Kuhnle, (ed.), Survival of the European Welfare State (London: Routledge). 
Evans, M. and Davies, J. (1999) 'Understanding Policy Transfer: A Multi-Level, Multi-Disciplinary Perspective', Public Administration, 77, 2, 361-85.

FACS: Department of Family and Community Services, Australia (1998) Annual Report 1997/8. (www.facs.gov.au/internet/facsinternet.nsf/aboutfacs/respubs)

FACS: Department of Family and Community Services, Australia (2000) Annual Report 1999/2000. (www.facs.gov.au/internet/facsinternet.nsf/aboutfacs/respubs)

Finn, D. (1997) Working Nation: Welfare reform and the Australian Job Compact for the long-term unemployed, London: the Unemployment Unit.

Garrison $* * * * * * * * * * * * * * * * * * * * * *$ in J.T. Oldham and M.S. Melli, (eds), Child Support the Next Frontier, Ann Arbor: University of Michigan Press, pp.

Harman, H. (1996) Getting Welfare to Work: Opportunities for lone mothers (London: Labour Party) Haas, P. (1992) 'Introduction: Epistemic Communities and International Policy Coordination', International Organization, 46, 1, 1-35.

Heclo, H. (1974) Modern Social Politics in Britain and Sweden, London: Yale University Press.

Hewitt, P. (2000) 'A new Network for a Common Purpose' (www.policy-network.org)

Jupp, J. (1964) 'Their Labour and Ours' in H. Mayer (ed) Australian Politics: A Reader. Melbourne: Cheshire.

Kalisch, D.W. (2000) Social Policy directions across the OECD region: reflections on a decade of change, Paris: OECD.

Keating, P. (1994) Working Nation: the White Paper on Employment and Growth, (Canberra: Australian Government Publishing Service).

Keating, P. (1999) 'Life Membership acceptance speech' (www.keating.org.au)

Kelly, P. (1976) The Unmaking of Gough, Sydney: Angus and Robertson.

Kelly, P. (1994) The End of Certainty. Sydney: Allen and Unwin.

King, D. and Wickham-Jones, M. (1999) 'From Clinton to Blair: The Democratic (Party) Origins of Welfare to Work', Political Quarterly, 70, 1, 62-74

Labour Party, UK (1996) Getting Welfare to Work: A New Vision for Social Security, London: Labour Party.

Labour Party (UK) (1997) New Labour: Because Britain Deserves Better: General Election Manifesto. London: Labour Party.

Latham, M. (1998) Civilising Global Capital: New Thinking for Australian Labour. St Leonard's, N.S.W.: Allen and Unwin.

Layard, R. ,with assistance from Andrew Sentance, (1986)

How to Beat Unemployment, Oxford: Oxford University Press.

Maclean, M. and Warman, A. (2000) 'A Comparative Approach to Child Support Systems: Legal Rules and Social Policies', in J.T. Oldham and M.S. Melli, (eds), Child Support the Next Frontier, Ann Arbor: University of Michigan Press, pp. 166-79.

McQueen, H. 1970 A New Britannia: An Argument Concerning the Social Origins of Australian Radicalism and Nationalism. Harmondsworth: Penguin.

Mead, L.M. 1991 'The New Politics of Poverty', The Public Interest, 103, Spring.

Millar, J. (1996) 'Family Obligations and Social Policy: The Case of Child Support', Policy Studies, $17,3,181-93$.

Millar, J. (2000) 'Lone Parents and the New Deal', Policy Studies, 21, 4, 333-45

Millar, J. and Whiteford, P. (1993) 'Child Support in lone-parent families: policies in Australia and the UK', Policy and Politics, 21, 1, 59-72.

Murray, C. 1982 'The Two Wars Against Poverty', The Public Interest, 69, Winter.

OECD (1987) Structural Adjustment and Economic Performance, Paris: OECD.

OECD (1988) Reforming Public Pensions, Paris: OECD.

OECD, (1994) The Jobs Study, Paris: OECD.

Page, E.C. (2000) 'Future Governance and the Literature on Policy Transfer and Lesson Drawing', Hull, University of Hull/ESRC.

Phillips, M. (1997) Workfare for Lone Mothers: A Solution to the Wrong Problem?' in A. Deacon (ed), From Welfare to Work: Lessons from America, pp. 120-6, London, IEA.

Pierson, C. (1998) Beyond the Welfare State? the New Political Economy of Welfare, Cambridge, Polity. 
Rose, R. (1991) What is Lesson-Drawing? Glasgow: Strathclyde Studies in Public Policy 190.

Rose, R. (1993) Lesson-Drawing in Public Policy: A Guide to Learning Across Time and Space, London, Chatham House.

Rose, R. (2000) 'What can we learn from Abroad?', Parliamentary Affairs, 53, 628-43.

Scott, A. (2000)Running on Empty: 'Modernising' the British and Australian Labour Parties, Sydney: Pluto Press.

Social Justice Commission, IPPR (1994) Social Justice: Strategies for renewal, London: Vintage.

Shaw, E. (1996)The Labour Party Since 1945, Oxford: Blackwell/I.C.B.H.

Stone, D. (1999) 'Learning Lessons and Transferring Policy across Time, Space and Disciplines', Politics, 19, 1, 51-9.

Stone, D. (2000) 'Non-Governmental Policy Transfer: The Strategies of Independent Policy Institutes', Governance, 13, 1, 45-62.

Walker, J. (1969) 'The diffusion of innovations among the American states', the American Political Science 